\title{
Ear-related problems among children attending the paediatric and otorhinolaryngology out-patients clinics of the University of Nigeria Teaching Hospital, Enugu.
}

\author{
Ilechukwu GC $\mathrm{C}^{1}$, Ilechukwu CGA ${ }^{1}$, Ezeanolue $\mathrm{BC}^{2}$, Okoroafor $\mathrm{IJ}^{2}$, Ojinnaka $\mathrm{NC}^{3}$, \\ Ubesie $\mathrm{AC}^{3}$, Emechebe $\mathrm{GO}^{4}$, Eze J ${ }^{5}$
}

1. Whiston Hospital, St Helen's and Knowsley Teaching Hospital NHS Trust, Prescot, United Kingdom.

2. Department of Orthorhinolaryngology, University of Nigeria Teaching Hospital, Enugu.

3. Department of Paediatrics, University of Nigeria Teaching Hospital, Enugu

4. Department of Paediatrics, Anambra State University Teaching Hospital, Awka

5. Royal Victoria Infirmary, New Castle

\begin{abstract}
Background: Ear related diseases are commonly seen in clinics worldwide especially among children. They are associated with significant morbidity and frequent hospital visits. Limited data exists regarding the burden of ear disease among Nigerian children.

Objective: To determine the prevalence of ear-related problems among children presenting at the Paediatric and Otorhinolaryngology clinics of the University of Nigeria Teaching Hospital, Enugu.

Materials and methods: This was a cross-sectional study conducted at the Paediatric and Otorhinolaryngology Clinics of the University of Nigeria Teaching Hospital Enugu. All children aged 0 and 17 years presenting between $1^{\text {st }}$ June and $31^{\text {st }}$ August 2006 with ear-related problems were enrolled consecutively into the study. Data analysis was by SPSS version 11.

Results: Three thousand and twenty-one children were seen during the study period. Out of these, 248 children $(8.2 \%)$ presented with ear-related problems. Chronic otitis media (30.5\%), acute otitis media (29.9\%), cerumen auris (11.3\%), otitis externa(10.1\%), hearing impairment $(7.3 \%)$ and foreign body in the ear $(5.7 \%)$ were the most commonly diagnosed ear-related problems.

Conclusion: Ear-related problems among children presenting at the UNTH Enugu were not uncommon. However, otitis media was the most commonly diagnosed ailment affecting the ears in children.

Keywords: Ear-related problems, children, Enugu, otitis media

DOI: http://dx.doi.org/10.4314/ahs.v16i2.4

Cite as: Ilechukwn GC, Ilechukwn CGA, Ezeanolue BC, Okoroafor IJ, Ojinnaka NC, Ubesie AC, et al. Ear-related problems among children attending the paediatric and otorbinolaryngology out-patients clinics of the University of Nigeria Teaching Hospital, Enugu. Afri Health Sci 2016;16(2): 363-366. bttp:// dx.doi.org/10.4314/abs.v16i2.4
\end{abstract}

\section{Introduction}

Ear-related problems are commonly found in Paediatric and Otorhinolaryngology Clinics. ${ }^{1,2}$ In the United States of America, diseases of the ear in children cause much concern in the medical and non-medical world because of the huge financial implications and loss of school and work days for both children and parents. The psychologi-

$$
\begin{aligned}
& \text { Corresponding author: } \\
& \text { Ilechukwu Gideon Chukwudalu, } \\
& \text { Department of Paediatrics, } \\
& \text { Whiston Hospital, St Helen's } \\
& \text { and Knowsley NHS trust, } \\
& \text { Prescot, United Kingdom. } \\
& \text { Email: chummyandgideon@yahoo.com }
\end{aligned}
$$

cal stress posed by this group of diseases is not quantifiable as the complications of ear-related illnesses could be devastating. ${ }^{5}$ Otitis media is the most widely reported ear-related problem by clinicians. ${ }^{2,3}$ It can manifest as acute otitis media, chronic otitis media, otitis media with effusion or glue ear. ${ }^{4}$

In a community-based study in Ife Central Local Government Area of Osun State, Nigeria, the overall prevalence of otitis media was $14.7 \%$. This consisted of acute otitis media in $11.8 \%$, chronic suppurative otitis media (CSOM) in $2.5 \%$ and otitis media with effusion in less than 1\%. ${ }^{6}$ Earlier studies done in $\mathrm{Jos}^{7}$ and in Enugu, ${ }^{2} \mathrm{Ni}-$ geria also documented that chronic otitis media was the most common form ear-related problem at these centers. 
This study sought to up-date the pattern of ear-related problems among children aged one month to 17 years seen at the University of Nigeria Teaching Hospital, Enugu.

\section{Patients and methods}

This was a cross-sectional study in which consecutive children presenting at the University of Nigeria Teaching Hospital (UNTH) Enugu with ear-related problems were enrolled. The study was carried out at the Paediatric and Otorhinolaryngology Clinics of the Teaching Hospital between $1^{\text {st }}$ June and $31^{\text {st }}$ August, 2006. The inclusion criteria were age one month to 17 years, presence of earrelated complaints, and informed consent from caregivers of the children. Older children with discharging otitis media who refused to assent to the study were excluded.

Structured questionnaires were used to obtain relevant information about subjects. Symptoms of the patients and duration of ear discharge/problem were recorded on these questionnaires. Auroscopy was carried out on all the children who had ear-related problems and findings were appropriately recorded. The auroscopy was per- formed by one of the paediatricians and then confirmed by the otolaryngologist. Among patients diagnosed with otitis media, ear symptoms of less than 6 weeks duration was defined as acute otitis media; and chronic otitis media if $\geq 6$ weeks.

Ethical approval was obtained from the Health Research and Ethics Committee of the University of Nigeria Teaching Hospital. Consent was obtained from the parents and caregivers of the children as well as assent from the older children. Data analysis was with Statistical Package for Social Sciences (SPSS) version 11.

\section{Results}

A total of 2,822 patients were seen at the Paediatric Outpatients Clinic during the study period. One hundred and twenty-two $(4.3 \%)$ of them, aged $0-17$ years presented with ear-related problems. Among these 122 children, acute otitis media was the most common ear problem (48.4\%), followed by (CSOM) (37.7\%), foreign body in the ear $(4.9 \%)$, cerumen auris $(3.3 \%)$, hearing impairment $(1.6 \%)$, trauma to the ear $(1.6 \%)$, aural polyp $(0.8 \%)$ and otitis externa $(1.6 \%)$ as shown in Table 1.

\section{Table 1: Ear-related problems seen at the Out-patients Paediatric and Otorhinolaryngology Clinics and their frequencies}

\begin{tabular}{llll}
\hline Diagnosis & $\begin{array}{l}\text { Children's Clinic } \\
\text { Frequency (\%) }\end{array}$ & $\begin{array}{l}\text { Otorhinolaryngology } \\
\text { Clinic } \\
\text { Frequency (\%) }\end{array}$ & Total (\%) \\
\hline CSOM* & $46(37.8)$ & $29(23.0)$ & $75(30.2)$ \\
Acute otitis media & $59(48.4)$ & $15(11.9)$ & $74(29.8)$ \\
Cerumen auris & $4(3.3)$ & $25(19.7)$ & $29(11.7)$ \\
Otitis externa & $2(1.6)$ & $23(18.3)$ & $25(10.1)$ \\
Hearing & $2(1.6)$ & $16(12.7)$ & $18(7.3)$ \\
impairment & $6(4.9)$ & $8(6.4)$ & $14(5.7)$ \\
Foreign body & $2(1.6)$ & $4(3.2)$ & $3(1.4)$ \\
Trauma & $1(0.8)$ & $2(1.6)$ & $2(0.80)$ \\
Aural polyp & - & $2(1.6)$ & $2(0.8)$ \\
Mastoid abscess & $2(1.6)$ & \\
Otitis media with & - & & $248(100.0)$ \\
effusion & & $126(100.0)$ & \\
\hline Total & $122(100.0)$ & & \\
*CSOM = Chronic suppurative otitis media & & \\
& & &
\end{tabular}


At the Otorhinolaryngology Clinic, 199 children were seen during the study period and $126(63.3 \%)$ of them had ear-related problems. Among the 126 with ear-related problems, CSOM (23.0\%) was the most common, followed by cerumen auris $(19.8 \%)$, hearing impairment $(12.7 \%)$, acute otitis media $(11.9 \%)$, otomycosis $(11.1 \%)$, acute otitis externa $(7.1 \%)$, foreign body in the ear $(6.3 \%)$, trauma to the ear $(3.2 \%)$, aural polyp $(1.6 \%)$, mastoid abscess $(1.6 \%)$, glue ear or otitis media with effusion $(1.6 \%)$ as shown in see Table 1 . The overall prevalence of earrelated problems in children seen at the University of Nigeria Teaching Hospital, Enugu was 8.2\%.

\section{Discussion}

The finding in this study showed that chronic otitis media was the most common ear-related problem at the UNTH, Enugu and this agrees with previous study by Okafor in Enugu. ${ }^{2}$ However, our study showed that the proportion of children with CSOM was lower. This difference could be due to the fact that Okafor included both adults and children in his study unlike the current study that involved only children. ${ }^{2}$ We also reported a high incidence of acute otitis media in this study. Over all, otitis media (acute and chronic) accounted for more than half of the total number of ear-related problems documented in this study. This agrees with the findings by Bhatia and Varughese in Jos, Nigeria. ${ }^{7}$ Similarly, Fasunla et $\mathrm{al}^{8}$ in southwest Nigeria documented otitis media in $45 \%$ of their subjects who were aged $\leq 15$ years.

A possible explanation for rate of otitis media among the paediatric age group is the high incidence of upper respiratory tract infections among children. Nasopharyngitis in particular set the stage for acute otitis media by allowing spread ofpathogenic organisms from the nasopharynx into the middle ear via the Eustachian tube. ${ }^{9}$ It is interesting that acute otitis media was most common presentation of ear-related problems among the children seen at the Paediatric Outpatient clinic while CSOM was the most common among those seen in the Otorhinolaryngology Clinic. In a prospective study carried out inthe Otorhinolaryngology Clinic of the University of Ilorin Teaching Hospital in North-central Nigeria, children less than 10 years accounted for more than half of the CSOM seen over a seven month period. ${ }^{10}$ When poorly treated, acute otitis media often leads to chronic otitis media. The interplay between poverty and ignorance is also a major factor in the development of the chronic variety of otitis media especially in developing countries. ${ }^{11}$ Most cases of acute otitis media usually present and get treated at the Paediatric Outpatient Clinics. In the event of an ear discharge however, mothers are more likely to be referred to the Otorhinolaryngologists.

The incidence of Cerumen auris - the third most common ear-related problem seen in subjects agrees with the study by Okafor. ${ }^{2}$ In a cross sectional study of 620 students aged between 5 and 38 years with profound hearing loss in North-western Nigeria, impacted Cerumen auris was the most commonly reported otologic problem. ${ }^{12}$ The high incidence and the type of Cerumen auris in our environment may be related to race. ${ }^{13}$ Otitis externa were less common in this study and their incidences were lower than previously reported. ${ }^{2}$ The incidence of foreign body in this study was $(5.7 \%)$ which was also lower than previously reported. ${ }^{7}$ In the study by Fasunla in South West Nigeria, foreign body in the ear was the second most frequent ear disorders among children aged $\leq 15$ years. ${ }^{8}$

The lower rate of foreign body in the current study can partly be explained by the inclusion of older children (up to 17 years) in the study, who are more likely to be knowledgeable about dangers of inserting foreign bodies in their ears. In addition, the study in the South West Nigeria was in the Otorhinolaryngology unit only, unlike the current study that recruited participants from both the Otorhinolaryngology and Paediatric units. The main stay in the management of foreign bodies is surgery and such patients are therefore, more likely to be seen by the Otorhinolaryngologists. Mastoid abscess is a known ear-related problem and it is usually a complication of chronic suppurative otitis media. The incidence in this study was low $(0.8 \%)$ which is similar to the incidence documented by Ibekwe in Enugu. ${ }^{14}$ Our low incidence of otitis media with effusion could be, because impedance audio was not a routine tool used for patient assessment among the study population.

\section{Conclusion}

Ear-related problems in children are not uncommon in Enugu, the most common ones being acute and chronic otitis media. More studies are therefore needed to deter- 
mine the epidemiology and aetiology of ear-related problems in paediatric age group.

\section{References}

1. Lehmann D, Arumugaswamy A, Elsbury D, Finucane J, Stokes A, Monch R et al. Paediatr Perinat Epidemiol 2008; 22: $60-71$.

2. Okafor BC. Pattern of diseases of the ear: Otolaryngology in South -Eastern Nigeria. Nig Med J 1983; 13(1): 11-9.

3. Heinrich J, Raghuyamshi VS. Curr Allergy Asthma Rep 2004; 4: $302-9$.

4. American Academy of Pediatrics. Diagnosis and management of acute otitis media. Pediatrics 2004; 113: $1415-$ 65.

5. Jackson JM, Mourino AP. Pacifier use and otitis media in infants twelve months of age or younger. Pediatr Dent 1999; 21: $255-60$.

6. Amusa YB, Ijadunola IKT, Onayade OO. Epidemiology of otitis media in a local tropical African population. West Afr J Med 2005; 24(3): 227-30.

7. Bhatia PL, Varughese R. Pattern of otolaryngological diseases in Jos community. Nig Med J 1987; 2: 67-73.

8. Fasunla JA, Samdi M, Nwaorgu OG. An audit of Ear, Nose and Throat diseases in a tertiary health institution in South-western Nigeria. The Pan African Medical Journal.
2013;14: 1. [Online]. Available from: http://www.panafrican-med-journal.com/content/article/14/1/full/. (Accessed March 31, 2015).

9. Ilechukwu GC, Ilechukwu CGA, Ubesie AC, Ojinnaka CN, Emechebe GO, Iloh KK . Otitis Media in Children: Review Article. Open Journal of Pediatrics 2014; 4:47-53. Available from: http://dx.doi.org/10.4236/ ojped.2014.41006. (Accessed February 8, 2016).

10. Afolabi O, Salaudeen A, Ologe F, Nwabuisi C, Nwawolo C. Pattern of bacterial isolates in the middle ear discharge of patients with chronic suppurative otitis media in a tertiary hospital in North central Nigeria. African Health Sciences. 2012;12: 362-367.

11. Olatoke F, Ologe FE, Nwawolo CC, Saka MJ. The prevalence of hearing loss among school children with chronic suppurative otitis media in Nigeria and its effect on academic percormance. ENT Journal 2008; 87(12): $1-7$.

12. Ahmed AO, Kolo ES, Abah ER, Oladigbolu KK. An appraisal of common otologic disorders as seen in a deaf population in North-Western Nigeria. Ann Afr Med 2012;11:153-6.

13. Matsunaga E. The dimorphism in human normal cerumen. Ann Hum Genet 1962; 25: 273.

14. Ibekwe AO. Chronic suppurative otitis media in children. Nig J Paediatr 1985; 12: 17 -9. 